\title{
The relationships between potassium intakes, transmural potential difference of the rumen epithelium and magnesium absorption in wethers
}

\author{
S. Jittakhot, J. Th. Schonewille*, H. S. Wouterse, C. Yuangklang and A. C. Beynen \\ Department of Nutrition, Faculty of Veterinary Medicine, Utrecht University, P. O. Box 80.152, 3508 TD Utrecht, \\ The Netherlands
}

(Received 21 May 2003 - Revised 6 October 2003 - Accepted 15 October 2003)

\begin{abstract}
In vitro studies with isolated sheep rumen epithelium have shown that an increase in the lumen $\mathrm{K}$ concentration induces an increase in the transmural potential difference across the rumen epithelium (serosal side: positive), which is associated with a decrease in Mg transport. However, at lumen $\mathrm{K}$ concentrations $>80 \mathrm{mmol} / \mathrm{l}, \mathrm{Mg}$ transport across the epithelium became independent of the lumen $\mathrm{K}$ concentration. The present study was carried out to determine whether this observation also occurs in vivo. Four ruminally fistulated wethers were fed four rations supplemented with $\mathrm{KHCO}_{3}(15 \cdot 7,37 \cdot 6,59.4$ or $77.4 \mathrm{~g} \mathrm{~K} / \mathrm{kg} \mathrm{DM})$ in a $4 \times 4$ Latin square design. Increased $\mathrm{K}$ intakes significantly increased the rumen $\mathrm{K}$ concentration. For all data combined, $\mathrm{Mg}$ absorption expressed as $\%$ intake was negatively correlated with the rumen $\mathrm{K}$ concentration. However, apparent $\mathrm{Mg}$ absorption either expressed in absolute terms $(\mathrm{g} / \mathrm{d})$ or as \% intake was not significantly affected when the dietary K concentration was increased from 59.4 to $77.4 \mathrm{~g} / \mathrm{kg} \mathrm{DM}$. Rumen K concentration was inversely correlated with the transmural potential difference (blood side: positive) (Pearson's $r-0.709 ; R_{\text {adj }}^{2} 0 \cdot 468, P=0.002, n 16$ ). It is concluded that in wethers apparent $\mathrm{Mg}$ absorption becomes independent of the dietary $\mathrm{K}$ concentration when the $\mathrm{K}$ concentration is $>60 \mathrm{~g} / \mathrm{kg} \mathrm{DM}$ or equivalent to a postprandial rumen $\mathrm{K}$ concentration of about $125 \mathrm{mmol} / \mathrm{l}$.
\end{abstract}

Magnesium absorption: Potassium intake: Transmural potential difference: Sheep

Pastures in areas with intensive livestock production are generally rich in K (Fisher et al. 1994; Schonewille et al. 1997) due to frequent fertilization with manure, which may be injected directly into the soils (Schonewille et al. 1997). Consequently, $\mathrm{K}$ concentrations of $\geq 35 \mathrm{~g} / \mathrm{kg} \mathrm{DM}$ are common in fresh grass. Grazing cattle on such pastures entails the risk of hypomagnesaemia (Kemp, 1960), primarily due to a $\mathrm{K}$-induced decrease in $\mathrm{Mg}$ absorption (Fontenot et al. 1989). In ruminant animals, $\mathrm{Mg}$ absorption mainly takes place in the rumen (Rogers \& Van't Klooster, 1969; Tomas \& Potter, 1976) and consists of a K-insensitive, carrier-mediated process and a K-sensitive, electrogenic transport component (Leonhard et al. 1989). $\mathrm{Mg}$ uptake through the electrogenic transport component depends on the concentration of $\mathrm{Mg}$ in the soluble fraction of rumen contents and the apical membrane potential (PDa) across the rumen epithelial cells (intracellular contents are negative relative to rumen contents). At low rumen $\mathrm{K}$ concentrations, the $\mathrm{PDa}$ provides a driving force for $\mathrm{Mg}$ uptake by rumen epithelial cells, but high rumen $\mathrm{K}$ concentrations cause a depolarization of the PDa; this reduces Mg uptake (Leonhard-Marek \& Martens, 1996). Thus, the observed decrease in $\mathrm{Mg}$ absorption at high rumen $\mathrm{K}$ concentration is caused by the $\mathrm{K}$-induced change in the PDa. Since the transmural potential difference (PDt) is directly related to PDa, it follows that a change in PDa causes an alteration of PDt (LeonhardMarek \& Martens, 1996). Indeed, it was shown that the $\mathrm{K}$-induced decrease in $\mathrm{Mg}$ absorption was highly correlated with an increased PDt (Martens \& Blume, 1986; Martens et al. 1987).

It has been demonstrated (Ferreira et al. 1966; Leonhard-Marek \& Martens, 1996) that, under in vitro conditions with isolated sheep rumen epithelium, both PDt and PDa are correlated with the logarithm of the lumen K concentrations. This means that the change in PDt and PDa is much greater when the lumen $\mathrm{K}$ concentration increases from 20 to $40 \mathrm{mmol} / \mathrm{l}$ compared with the same increase from a concentration of $80 \mathrm{mmol} / \mathrm{l}$. Indeed, net $\mathrm{Mg}$ fluxes became independent of lumen $\mathrm{K}$ at concentrations $>80 \mathrm{mmol} / \mathrm{l}$ (Leonhard-Marek \& Martens, 1996), which implies that the K-induced reduction in $\mathrm{Mg}$ absorption might be non-linear under practical feeding conditions. Balance data from sheep indicate that the depressant effect of supplemental $\mathrm{K}$ on $\mathrm{Mg}$ absorption becomes lower at higher initial dietary $\mathrm{K}$ concentrations (Greene 
et al. 1983a,b; Grings \& Males, 1987). Furthermore, in an experiment with sheep it was shown that extra $\mathrm{K}$ did not affect $\mathrm{Mg}$ absorption when the dietary $\mathrm{K}$ content was increased from the high initial value of 39 to $82 \mathrm{~g} / \mathrm{kg} \mathrm{DM}$ (Rahnema \& Fontenot, 1986). Because neither rumen K concentrations nor PDt were measured in those feeding studies, the proposed mechanism of the K-induced inhibition of $\mathrm{Mg}$ absorption described earlier remains to be validated in vivo. Thus, we studied the effect of increasing $\mathrm{K}$ intakes on the PDt and $\mathrm{Mg}$ absorption to check the linearity of the $\mathrm{K}$-induced decrease in $\mathrm{Mg}$ absorption under feeding conditions. $\mathrm{K}$ intake was increased by supplementing the basal concentrate with $\mathrm{KHCO}_{3}$, which is as effective as intrinsic $\mathrm{K}$ salts in depressing $\mathrm{Mg}$ absorption (Schonewille et al. 1999b). Therefore, $\mathrm{KHCO}_{3}$ was used to obtain a range of $15-75 \mathrm{~g} \mathrm{~K} / \mathrm{kg} \mathrm{DM}$, which is beyond the practical range of $23-49 \mathrm{~g} \mathrm{~K} / \mathrm{kg}$ DM (Centraal Veevoederbureau, 2003), but it was anticipated that the chosen range of dietary $\mathrm{K}$ concentrations would enhance the interpretation of the data.

\section{Materials and methods}

\section{Animals and experimental design}

The experimental protocol was approved by the Animal Experiments Committee of the Utrecht Faculty of Veterinary Medicine. Four ruminally fistulated Zwartbles wethers were used. They were 1.5 years old and weighed 61 (SE 1.22) kg. The wethers had been fistulated at least 1 month before the start of the experiment. They were housed in individual pens $(1.9 \times 1.2 \mathrm{~m})$ with a layer of wood shavings, or in metabolism crates with slatted floors. The trial had a $4 \times 4$ Latin square design and was preceded by $14 \mathrm{~d}$ pre-experimental period. The wethers were randomly assigned to each sequence of feeding of the four experimental rations. Each experimental period lasted $28 \mathrm{~d}$. Tap water was available ad libitum.

\section{Experimental diets}

The experimental diets were formulated by the addition of appropriate amounts of $\mathrm{KHCO}_{3}$ to the basal concentrate. The ingredient composition of the pelleted concentrates (diameter $3 \mathrm{~mm}$ ) is shown in Table 1. During the pre-experimental period, all wethers were offered $582 \mathrm{~g}$ commercial concentrate and $129 \mathrm{~g}$ hay/d. Thereafter, the sheep were fed one of the four experimental diets. The amount of feed offered and the analysed composition of the experimental diets are shown in Table 2. The wethers were fed a restricted amount of the experimental diets so as to maintain constant intakes of non-variable nutrients; the calculated metabolizable energy intake was $7.5 \mathrm{MJ} / \mathrm{d}$ for each diet (Centraal Veevoederbureau, 2003). In each $24 \mathrm{~h}$ interval the diets were offered three times per $\mathrm{d}$ in three equal portions; the portions were given at 00.00, 08.00 and 16.00 hours.

\section{Sample collection}

The experimental concentrates and hay were sampled from days 18 to 28 of each period, were ground, and
Table 1. Compositions of the experimental concentrates

\begin{tabular}{lrrrr}
\hline & \multicolumn{4}{c}{ Experimental concentrate } \\
\cline { 2 - 5 } & Low K & Medium K & High K & Extreme K \\
\hline $\begin{array}{l}\text { Ingredients (g) } \\
\text { Constant } \\
\quad \text { components* }\end{array}$ & 994 & 994 & 994 & 994 \\
$\quad \mathrm{MgO}^{\mathrm{KHCO}}{ }_{3}$ & 6 & 6 & 6 & 6 \\
$\quad$ Total & 0 & 66 & 132 & 198 \\
& 1000 & 1066 & 1132 & 1198 \\
\hline
\end{tabular}

* The constant components consisted of $(\mathrm{g})$ : sugarbeet pulp 250, soyabean meal 200, sugarcane molasses 37 , linseed meal 120 , maize gluten feed 150, maize meal 230, $\mathrm{NaCl} 5$, premix 2. The premix consisted of $(\mathrm{mg} / \mathrm{g})$ : $\mathrm{ZnSO}_{4} . \mathrm{H}_{2} \mathrm{O} 67.5, \mathrm{MnSO}_{4} \cdot \mathrm{H}_{2} \mathrm{O} 57.5, \mathrm{CuSO}_{4} \cdot \mathrm{H}_{2} \mathrm{O} 25 \cdot 0, \mathrm{KIO}_{3} 0.6, \mathrm{CoSO}_{4} .7-$ $\mathrm{H}_{2} \mathrm{O} 0.4, \mathrm{Na}_{2} \mathrm{SeO}_{3} .5 \mathrm{H}_{2} \mathrm{O} 0.4$, retinyl acetate preparation 0.9 , cholecalciferol preparation $4 \cdot 2, \alpha$-tocopheryl acetate preparation $25 \cdot 0, \mathrm{CaCO}_{3} 818.5$.

subsequently stored in a sealed jar at room temperature $\left(18^{\circ} \mathrm{C}\right)$. From days 18 to 25 of each experimental period, faeces were collected quantitatively. The $24 \mathrm{~h}$ faeces collections were stored at $-18^{\circ} \mathrm{C}$ in plastic bags. At the end of each experimental period, the faeces collections were pooled for each wether and mixed thoroughly. Two samples each representing $10 \%$ total faeces collection from each wether for each experimental period were dried for $5 \mathrm{~d}$ at $60^{\circ} \mathrm{C}$, ground, and stored in a sealed jar at room temperature.

On day 26 of each experimental period, before the morning meal, $70 \mathrm{ml} \mathrm{Cr-EDTA}$ solution ( $100 \mathrm{~g} \mathrm{Cr}-\mathrm{EDTA} / \mathrm{l}, \mathrm{pH}$ 6.5-6.7) was introduced into the rumen by the cannula as a marker to assess rumen volume and passage rate of the rumen liquid phase. Samples of the rumen contents

Table 2. Intake and analysed compositions of the experimental rations

\begin{tabular}{|c|c|c|c|c|}
\hline & \multicolumn{4}{|c|}{ Experimental ration } \\
\hline & Low $\mathrm{K}$ & Medium K & High $\mathrm{K}$ & Extreme $\mathrm{K}$ \\
\hline \multicolumn{5}{|l|}{$\begin{array}{r}\text { Intake (g DM per } \\
\text { sheep per d) }\end{array}$} \\
\hline $\begin{array}{l}\text { Experimental } \\
\text { concentrate* } \dagger\end{array}$ & 535 & 571 & 603 & 638 \\
\hline Hay & 121 & 121 & 121 & 121 \\
\hline Total DM & 656 & 692 & 724 & 759 \\
\hline \multicolumn{5}{|c|}{ Nutrient composition of total rations (g/kg DM) } \\
\hline $\begin{array}{l}\text { Crude protein } \\
\quad(\mathrm{N} \times 6.25)\end{array}$ & 166 & 167 & 162 & 154 \\
\hline Crude fat & 35 & 30 & 29 & 29 \\
\hline Crude fibre & 122 & 119 & 111 & 110 \\
\hline $\mathrm{Mg}$ & $5 \cdot 8$ & $5 \cdot 7$ & 5.5 & $5 \cdot 2$ \\
\hline $\mathrm{K}$ & $15 \cdot 7$ & $37 \cdot 6$ & $59 \cdot 4$ & $77 \cdot 4$ \\
\hline $\mathrm{Na}$ & $2 \cdot 7$ & $2 \cdot 6$ & 2.4 & $2 \cdot 3$ \\
\hline $\mathrm{Ca}$ & 5.4 & $5 \cdot 2$ & $5 \cdot 0$ & 4.7 \\
\hline $\mathrm{P}$ & 4.7 & 4.6 & 4.4 & $4 \cdot 1$ \\
\hline
\end{tabular}

* For details of the composition of the concentrate, see Table 1.

†The analysed DM contents were as follows ( $\mathrm{g} / \mathrm{kg}$ concentrate): low $\mathrm{K} 919$, medium K 920 , high $\mathrm{K} 914$, extreme $\mathrm{K} 917$. The analysed mineral compositions of the concentrates were as follows (g/kg DM): low $\mathrm{K}: \mathrm{Mg} \mathrm{6.7}$, $\mathrm{K} 14.8$, Na 2.9, Ca 5.6, P 5.3; medium K: Mg 6.6, K 41.3, Na 2.8, Ca 5.4, $\mathrm{P}$ 5.1; high $\mathrm{K}: \mathrm{Mg} 6 \cdot 4, \mathrm{~K}$ 67.4, Na 2.6, Ca 5.2, P 4.8; extreme K: Mg 5.9, $\mathrm{K} 88 \cdot 3, \mathrm{Na} 2 \cdot 4, \mathrm{Ca} 4 \cdot 9, \mathrm{P} 4.5$

¥ The analysed DM content of hay was $935 \mathrm{~g} / \mathrm{kg}$ and the analysed composition was $(\mathrm{g} / \mathrm{kg} \mathrm{DM})$ : crude protein $(\mathrm{N} \times 6.25) 104$, crude fat 16 , crude fibre 312, Mg 1.4, K 19.7, Na 1.6, Ca 4.1, P 2.1. 
(approximately $30 \mathrm{ml}$ ) were taken at $07.30,09.00,10.00$, $11.00,13.00,15.00$ and 17.00 hours. The $\mathrm{pH}$ of the rumen contents was recorded immediately after collection. Thereafter, samples of rumen contents were centrifuged at room temperature at $2700 \mathrm{~g}$ for $15 \mathrm{~min}$ and the supernatant fractions were stored in plastic tubes at $-18^{\circ} \mathrm{C}$. A portion of the supernatant fraction was centrifuged at $30000 \mathrm{~g}$ for $30 \mathrm{~min}$ at $20^{\circ} \mathrm{C}$, and the supernatant fraction was stored in plastic tubes; this was not done for the sample of rumen contents taken at 10.00 hours. On day 27 of each experimental period, blood was taken between 14.00 and 14.30 hours from the jugular vein into evacuated heparinized tubes, centrifuged immediately for $10 \mathrm{~min}$ at $2700 \mathrm{~g}$; the plasma was collected and stored in a plastic tube at $-18^{\circ} \mathrm{C}$.

\section{Measurement of potential difference}

The PDa is of primary interest to explain the K-induced inhibition of $\mathrm{Mg}$ uptake by rumen epithelial cells, but it cannot be measured under feeding conditions. PDa is strongly correlated with PDt (Leonhard-Marek \& Martens, 1996). Therefore, we measured PDt in the present study. The measurement of the potential difference between blood (jugular vein) and rumen contents has been described by Schonewille et al. (1999a). PDt was measured continuously (09.00 to 15.00 hours) on day 28 of each period. Briefly, the PDt was monitored twice per s using an analogue to digital converter (Data Acquisition Board, PCI 20428W-1; Intelligent Instrumentation Inc., Tucson, AZ, USA) built into a computer. The analogue to digital converter was connected with two separate reference electrodes (REF201; Radiometer, Paris, France). Each electrode was dipped into $500 \mathrm{ml}$ saturated $\mathrm{KCl}$ solution $(3.5 \mathrm{M})$ and the rumen and blood electrodes were connected by saturated $\mathrm{KCl}-$ agar bridges.

\section{Chemical analyses}

$\mathrm{N}$ was determined by the macro-Kjeldahl method (International Dairy Federation, 1986); a factor of 6.25 was used to convert $\mathrm{N}$ mass into crude protein. Dithethyl ether extracts of the feedstuffs were prepared according to the Association of Official Analytical Chemists (1984); the solvent was evaporated and the crude fat residue was weighed. The crude fibre content of feedstuffs was estimated according to the method of the Association of Official Analytical Chemists (1984). Feedstuffs and faeces samples were ashed at $480^{\circ} \mathrm{C}$ for $6 \mathrm{~h}$ to enable analysis for $\mathrm{Mg}, \mathrm{K}, \mathrm{Na}, \mathrm{Ca}$ and $\mathrm{P}$. The ash samples were dissolved in $15 \mathrm{ml} 4 \mathrm{M}-\mathrm{HCl}$ and the acidified solution was analysed for $\mathrm{Mg}, \mathrm{Ca}$ and $\mathrm{K}$ by atomic absorption spectroscopy and for $\mathrm{Na}$ by atomic emission spectroscopy (Perkin Elmer 3110; Perkin Elmer Corp., Norwalk, CT, USA). Total P in feedstuffs was measured with a spectrophotometer following the method of Quinlan \& DeSesa (1955). The concentrations of $\mathrm{Mg}$ and $\mathrm{K}$ in rumen contents were determined directly by atomic absorption spectroscopy and those of $\mathrm{Na}$ and $\mathrm{Cr}(\mathrm{III})$ in rumen contents were measured directly by atomic emission spectroscopy (Ram et al. 1998). The accuracy of each assay run was found to be within $3.0 \%$ deviation from the target value of a commercial hay powder (CRM 129; Community Bureau of Reference, Brussels, Belgium) or from that of in-house reference samples. $\mathrm{Mg}$ concentration in plasma was measured directly by atomic absorption spectroscopy (Perkin-Elmer, 1982). The combined within- and between-run precision of the determinations (CV) was $\leq 3.0 \%$.

\section{Calculations and statistical analyses}

Before statistical analysis, the PDt data for each experimental animal were pooled for each measuring day. The calculations to obtain rumen volume and the passage rate of rumen contents have been described by Schonewille et al. (1999b). All data were subjected to ANOVA with animal, experimental period and dietary treatment as factors (Wilkinson, 1990). When the influence of treatment was significant, Tukey's $t$ test was used to identify diets with different effects on the variable involved. For the data from each sheep $(n 4)$ and for each diet $(n 4)$, linear correlations were calculated between rumen variables, PDt and $\mathrm{Mg}$ absorption. For the calculations it was assumed that the sixteen data points could be considered to be independent. To detect rumen variables that were related to $\mathrm{Mg}$ absorption, multiple regression analysis was performed (Wilkinson, 1990) with animal and period as factor, $\mathrm{Mg}$ absorption as dependent variable and rumen content concentrations of $\mathrm{Mg}$ and $\mathrm{K}$, rumen $\mathrm{pH}$, rumen volume, passage rate of rumen contents and PDt as independent variables. Forward stepwise regression was performed by incorporating into the model the rumen variable showing the highest significant partial correlation coefficient for its relationship with $\mathrm{Mg}$ absorption. Throughout, the level of significance was set at $P<0.05$.

\section{Results}

\section{Feed intake and body weight}

The wethers consumed all feed supplied. The experimental rations did not significantly influence the body weight of the sheep. For all treatments combined, body weight was $63(\operatorname{SE} 0 \cdot 3) \mathrm{kg}(n 4)$.

\section{Magnesium absorption and plasma magnesium}

Intakes of $\mathrm{Mg}$ were similar for all treatments (Table 3). Faecal Mg excretions were significantly increased after feeding the rations containing the two highest levels of $\mathrm{K}$; the difference in faecal $\mathrm{Mg}$ excretion between these two treatments was not significant. Consequently, both absolute $\mathrm{Mg}$ absorption (g/d) and $\mathrm{Mg}$ absorption expressed as $\%$ intake were significantly decreased on the high- and extreme-K rations. Because $\mathrm{Mg}$ intake was essentially constant, absolute $\mathrm{Mg}$ absorption (g/d) and $\mathrm{Mg}$ absorption expressed as \% intake were highly correlated (Pearson's $r$ 0.998, $P<0.001, n 16)$.

The difference in $\mathrm{K}$ intakes among treatments did not significantly affect plasma $\mathrm{Mg}$ concentrations. For all treatments combined, plasma $\mathrm{Mg}$ concentration was 1.0 (SE 0.03$) \mathrm{mmol} / \mathrm{l}(n 4)$. 
Table 3. Intake, faecal excretion and absorption of magnesium in wethers fed the experimental rations ${ }^{*}$ (Mean values for four sheep per group)

\begin{tabular}{|c|c|c|c|c|c|c|}
\hline & \multicolumn{4}{|c|}{ Experimental ration } & \multirow[b]{2}{*}{ SEM } & \multirow{2}{*}{$\begin{array}{c}\text { Statistical significance } \\
\text { of effect: } P_{\text {diet }}\end{array}$} \\
\hline & Low K & Medium K & High K & Extreme $\mathrm{K}$ & & \\
\hline Intake (g/d) & $3 \cdot 8$ & $3 \cdot 9$ & $4 \cdot 0$ & $3 \cdot 9$ & ND† & ND† \\
\hline Faeces $(\mathrm{g} / \mathrm{d})$ & $2 \cdot 2^{\mathrm{C}}$ & $2 \cdot 5^{\mathrm{bc}}$ & $3 \cdot 0^{\mathrm{a}}$ & $2 \cdot 7^{\mathrm{ab}}$ & 0.08 & 0.002 \\
\hline Absorption & & & & & & 0.006 \\
\hline$g / d$ & $1 \cdot 6^{\mathrm{a}}$ & $1 \cdot 4^{a b}$ & $1 \cdot 0^{\mathrm{C}}$ & $1 \cdot 2^{\mathrm{bc}}$ & 0.08 & \\
\hline$\%$ intake & $41 \cdot 9^{a}$ & $35 \cdot 4^{\mathrm{ab}}$ & $24 \cdot 5^{\mathrm{c}}$ & $30.9^{b c}$ & 1.92 & 0.004 \\
\hline
\end{tabular}

\section{Mineral concentrations in rumen contents, rumen $\mathrm{pH}$ and transmural potential difference}

$\mathrm{Mg}$ concentrations in rumen contents both before and after feeding were not significantly affected by the level of $\mathrm{K}$ intake (Table 4). Although ANOVA indicated a borderline significant influence of $\mathrm{K}$ intake on rumen $\mathrm{pH}$, significant differences between specific rations could not be identified by Tukey's $t$ test. There was a significant correlation between the mean postprandial rumen $\mathrm{pH}$ and the mean postprandial $\mathrm{Mg}$ concentration in rumen contents (Pearson's $r-0.663, P=0.005, n 16$ ).

The level of $\mathrm{K}$ intake significantly increased the rumen $\mathrm{K}$ concentrations and decreased the rumen $\mathrm{Na}$ concentrations in a dose-dependent fashion (Table 4). A strong negative correlation was observed between the mean postprandial $\mathrm{K}$ and $\mathrm{Na}$ concentrations in rumen contents (Pearson's $r-0.909, P<0 \cdot 001, n 16$ ).

The increase in $\mathrm{K}$ intake was associated with an increase in PDt (blood side: positive) (Table 4). The increase in the PDt after feeding the medium- $v$. low-K intake was not significant $(P=0.090)$, but PDt was significantly increased by the two highest levels of $\mathrm{K}$ intake when compared with the
low-K ration. There was a significant, positive association between the mean postprandial rumen $\mathrm{K}$ concentrations and the PDt; the linear regression was $y=43 \cdot 82+0 \cdot 17 x$ $\left(R_{\text {adjusted }}^{2} 0 \cdot 468, P=0 \cdot 002, n 16\right)$.

\section{Rumen volume and passage rate}

Rumen volume was significantly increased when dietary $\mathrm{K}$ intake was increased from the low to extreme level (Table 5). The fractional outflow $(\% / \mathrm{h})$ of the liquid phase was increased after feeding of the medium-K ration, but was not significantly different for the low, high and extreme levels of $\mathrm{K}$ intake. The absolute outflow rate of the liquid phase was not influenced by the level of $\mathrm{K}$ intake.

\section{Multiple regression analysis}

The multiple regression model with a constant, the factors (animal and experimental period) and the independent rumen variables ( $\mathrm{Mg}$ concentration, $\mathrm{PDt}$, rumen volume and passage rate of rumen contents) explained $78.8 \%$ of the observed variance in $\mathrm{Mg}$ absorption $(P=0 \cdot 025)$. After

Table 4. Rumen contents magnesium, potassium and sodium concentrations, and $\mathrm{pH}$ and transmural potential difference (PDt) in wethers fed the experimental rations*

(Mean values for four sheep per group)

\begin{tabular}{|c|c|c|c|c|c|c|}
\hline & \multicolumn{4}{|c|}{ Experimental ration } & \multirow[b]{2}{*}{ SEM } & \multirow{2}{*}{$\begin{array}{c}\text { Statistical significance } \\
\text { of effect: } P_{\text {diet }}\end{array}$} \\
\hline & Low K & Medium K & High K & Extreme $\mathrm{K}$ & & \\
\hline \multicolumn{7}{|l|}{$\mathrm{Mg}(\mathrm{mm})$} \\
\hline 07.30 hours & $8 \cdot 7$ & $5 \cdot 2$ & $7 \cdot 8$ & $7 \cdot 0$ & $1 \cdot 25$ & 0.327 \\
\hline Post-feeding $†$ & $9 \cdot 6$ & $12 \cdot 6$ & $10 \cdot 4$ & $8 \cdot 0$ & $1 \cdot 11$ & 0.116 \\
\hline \multicolumn{7}{|l|}{$\mathrm{K}(\mathrm{mm})$} \\
\hline 07.30 hours & $42 \cdot 9^{c}$ & $84 \cdot 3^{b}$ & $121 \cdot 2^{\mathrm{a}}$ & $142 \cdot 9^{a}$ & $5 \cdot 39$ & $<0.001$ \\
\hline Post-feeding $\dagger$ & $43.0^{d}$ & $87 \cdot 8^{C}$ & $126 \cdot 8^{b}$ & $155 \cdot 5^{a}$ & $5 \cdot 63$ & $<0.001$ \\
\hline \multicolumn{7}{|l|}{$\mathrm{Na}(\mathrm{mm})$} \\
\hline 07.30 hours & $100 \cdot 4^{a}$ & $54 \cdot 0^{b}$ & $30 \cdot 5^{\mathrm{b}}$ & $24 \cdot 9^{b}$ & $6 \cdot 88$ & 0.001 \\
\hline $\mathrm{pH}$ Post-feedingt & $94 \cdot 7^{\mathrm{a}}$ & $66 \cdot 3^{b}$ & $41 \cdot 8^{c}$ & $34 \cdot 7^{c}$ & $3 \cdot 67$ & $<0.001$ \\
\hline 07.30 hours & $6 \cdot 58$ & $6 \cdot 67$ & $6 \cdot 82$ & 6.92 & 0.082 & 0.089 \\
\hline Post-feedingt & 6.47 & 6.43 & $6 \cdot 64$ & 6.79 & 0.076 & 0.051 \\
\hline PDt $(\mathrm{mV}) \ddagger$ & $48 \cdot 2^{\mathrm{b}}$ & $60 \cdot 7^{\mathrm{ab}}$ & $71 \cdot 5^{\mathrm{a}}$ & $65 \cdot 3^{a}$ & 2.98 & 0.008 \\
\hline
\end{tabular}

a,b,c,d Mean values within a row with unlike superscript letters were significantly different (Tukey's $t$ test; $P<0.05$ ).

${ }^{*}$ For details of diets and procedures, see Tables 1 and 2 and p. 184.

† Geometrical mean values of samples taken at $09.00,11.00,13.00,15.00$ and 17.00 hours

$\ddagger$ Geometrical mean values of PDt values measured from 09.00 to 15.00 hours. 
Table 5. Rumen volume (RV) and passage rate (PR) of rumen contents in wethers fed the experimental rations* (Mean values for four sheep per group)

\begin{tabular}{|c|c|c|c|c|c|c|}
\hline & \multicolumn{4}{|c|}{ Experimental ration } & \multirow[b]{2}{*}{ SEM } & \multirow{2}{*}{$\begin{array}{c}\text { Statistical significance } \\
\text { of effect: } P_{\text {diet }}\end{array}$} \\
\hline & Low $\mathrm{K}$ & Medium K & High K & Extreme $\mathrm{K}$ & & \\
\hline $\begin{array}{l}\text { RV (litres) } \\
\text { PR }\end{array}$ & $4.9^{\mathrm{bc}}$ & $4 \cdot 3^{\mathrm{c}}$ & $5 \cdot 9^{\mathrm{ab}}$ & $6 \cdot 7^{a}$ & 0.33 & 0.008 \\
\hline$\% / \mathrm{h}$ & $4 \cdot 5^{\mathrm{ab}}$ & $6 \cdot 0^{\mathrm{b}}$ & $3.6^{\mathrm{a}}$ & $3 \cdot 5^{\mathrm{a}}$ & 0.48 & 0.040 \\
\hline $\mathrm{ml} / \mathrm{h}$ & 196 & 242 & 207 & 231 & $22 \cdot 4$ & 0.500 \\
\hline
\end{tabular}

a,b,c Mean values within a row with unlike superscript letters were significantly different (Tukey's $t$ test; $P<0.05$ ).

${ }^{*}$ For details of diets and procedures, see Tables 1 and 2 and p. 184.

forward stepwise regression it appeared that only the factors experimental period $(P<0.001)$ and PDt $(P<0.001)$ contributed significantly to the explained variance in $\mathrm{Mg}$ absorption, which became $83.3 \%$ (Table 6).

\section{Discussion}

The present study confirms earlier work showing that the addition of $\mathrm{KHCO}_{3}$ to the ration of ruminant animals inhibits $\mathrm{Mg}$ absorption (Newton et al. 1972; Poe et al. 1985; Wylie et al. 1985; Khorasani \& Armstrong, 1990; Schonewille et al. 1999a) and that the depressant effect of high $\mathrm{K}$ intake on $\mathrm{Mg}$ absorption is associated with an increase in the PDt (Schonewille et al. 1999a). In the current feeding trial the linear relationship between the observed PDt and $\mathrm{Mg}$ absorption was calculated to be: $y=65.27-0.52 x \quad\left(R_{\text {adjusted }}^{2} 0.239, \quad P=0.031, \quad n 16\right)$, which supports the mechanism proposed on the basis of studies with isolated rumen models. Furthermore, Leonhard-Marek \& Martens (1996) demonstrated that Mg absorption under in vitro conditions became independent from the lumen $\mathrm{K}$ concentration at a concentration $>80 \mathrm{mmol} / \mathrm{l}$. Indeed, when the PDt values measured after feeding the ration with $15.7 \mathrm{~g} \mathrm{~K} / \mathrm{kg} \mathrm{DM}$ are omitted from the dataset, PDt becomes independent from the mean postprandial $\mathrm{K}$ concentrations in rumen contents (Table 4). This independency is also illustrated by the lack of correlation between PDt and rumen $\mathrm{K}$ concentrations (Pearson's $r 0 \cdot 310, P=0 \cdot 326, n 12$ ). Furthermore, a significant linear relationship was calculated between the

Table 6. Multiple regression model accounting for $83.3 \%$ of the observed variance in magnesium absorption* ${ }^{*}$

(Regression coefficients with their standard errors)

\begin{tabular}{lcccc}
\hline $\begin{array}{l}\text { Independent } \\
\text { variable }\end{array}$ & Unit & $r \ddagger$ & SE & $\begin{array}{c}\text { Statistical } \\
\text { significance of } \\
\text { effect: } P_{\text {variable }}\end{array}$ \\
\hline $\begin{array}{l}\text { Constant } \\
\begin{array}{l}\text { Experimental } \\
\text { period }\end{array}\end{array}$ & $\begin{array}{c}\text { \% Mg intake } \\
\text { Rank order } \\
(2-4) \\
\text { PDt }\end{array}$ & $\begin{array}{c}66.3 \\
\mathrm{mV}\end{array}$ & 6.90 & $<0.001$ \\
& -0.61 & 0.11 & $<0.001$ \\
\hline
\end{tabular}

PDt, transmural potential difference; NG, not given.

${ }^{*}$ For details of diets and procedures, see Table 1 and p. 184

$\dagger P<0.001, n 16$.

$\ddagger$ The regression coefficient equals the change in average response of $\mathrm{Mg}$ absorption (\% intake) if the independent variable increases by one unit.

$\S N G$ because the values are not of interest and there were three regression coefficients for the factor period. logarithmically transformed rumen $\mathrm{K}$ concentration and PDt, the regression formula being PDt $(\mathrm{mV})=36.7 \mathrm{log}$ (rumen K) -10.7 (Pearson's $r 0.760, P=0.001, n 16$ ). The slope of this regression equation corresponds to the slopes reported by Scott (1966), Ferreira et al. (1966) and Martens \& Blume (1986), who reported values of $43,24 \cdot 4-39.7$ and $37 \cdot 1$ respectively.

Thus, on the basis of both in vitro observations (Leonhard-Marek \& Martens, 1996) and the present in vivo $\mathrm{PDt}$ measurements, $\mathrm{Mg}$ absorption should not be further depressed at dietary $\mathrm{K}$ concentrations $>37.6 \mathrm{~g} /$ $\mathrm{kg} \mathrm{DM}$ (medium $\mathrm{K}$ ) because the rumen $\mathrm{K}$ level then becomes $>80 \mathrm{mmol} / \mathrm{l}$ (Table 4). However, it appeared that $\mathrm{Mg}$ absorption was significantly reduced (Table 3) when the dietary $\mathrm{K}$ concentration increased from 37.6 (medium K) to $59.4 \mathrm{~g} / \mathrm{kg} \mathrm{DM}$ (high K), which was associated with an increase of the mean postprandial rumen $\mathrm{K}$ concentrations from 88 to $127 \mathrm{mmol} / \mathrm{l}$ (Table 4). In the present study, $\mathrm{Mg}$ absorption became independent from the dietary $\mathrm{K}$ concentration when it was increased from 59.4 (high K) to $77.4 \mathrm{~g} / \mathrm{kg} \mathrm{DM}$ (extreme K). The associated mean postprandial rumen $\mathrm{K}$ concentrations rose from 127 to $156 \mathrm{mmol} / 1$, whereas this increase was not accompanied by a further increase in PDt. Thus, it seems that under in vivo conditions $\mathrm{Mg}$ absorption may not be further depressed when rumen $\mathrm{K}$ concentrations are increased above values of approximately $125 \mathrm{mmol} / \mathrm{l}$.

$\mathrm{Mg}$ absorption dropped non-significantly from 41.9 to $35.4 \%$ intake when the dietary $\mathrm{K}$ concentration was increased from 15.7 to $37.6 \mathrm{~g} / \mathrm{kg} \mathrm{DM}$ (Table 3 ). In other words, in the current experiment $\mathrm{Mg}$ absorption dropped by 0.3 percentage units when the dietary $\mathrm{K}$ concentration was increased by $1 \mathrm{~g} / \mathrm{kg} \mathrm{DM}$. This value agrees with the outcome of previous experiments using wethers fed similar amounts of $\mathrm{KHCO}_{3}$ (Ram et al. 1998; Schonewille et al. 1999a). However, the observed decrease in Mg absorption of 6.5 percentage units in the current experiment was not statistically significant, which is probably related to the small number of animals used. In keeping with the work of McLean et al. (1985), the rumen $\mathrm{Na}$ concentration was linearly decreased when $\mathrm{K}$ intake was increased. $\mathrm{Na}$ absorption may be augmented through an increase in rumen $\mathrm{K}$ concentration as mediated by the difference in PDa (Martens et al. 1998).

In addition to the electrogenic component of $\mathrm{Mg}$ uptake by rumen epithelial cells, the chemical gradient of soluble $\mathrm{Mg}$ between the lumen and cell content is also of importance. The soluble $\mathrm{Mg}$ concentration depends on the rumen 
pH (Dalley et al. 1997). The Mg concentration in ultracentrifuged rumen contents can be affected by various factors including $\mathrm{Mg}$ intake, dietary $\mathrm{Mg}$ source, $\mathrm{Mg}$ solubility, and rumen volume and outflow (Van't Klooster, 1967). The soluble $\mathrm{Mg}$ concentration depends on the rumen $\mathrm{pH}$. At $\mathrm{pH}$ values $>6 \cdot 0$, a sharp fall in the concentration of soluble Mg was observed by Dalley et al. (1997); this may relate to the formation of insoluble magnesium (ammonium) phosphates (Axford et al. 1982). In our present study, rumen $\mathrm{pH}$ was positively correlated with rumen $\mathrm{K}$ concentrations. Because mean postprandial rumen $\mathrm{pH}$ and mean postprandial rumen $\mathrm{Mg}$ concentrations were negatively associated, it could be suggested that an increase in $\mathrm{K}$ intake also reduces $\mathrm{Mg}$ absorption by lowering the concentration of $\mathrm{Mg}$ in the rumen contents. Furthermore, rumen volume was increased with increasing $\mathrm{K}$ intakes (Table 5); this may have interfered with $\mathrm{Mg}$ absorption. However, on the basis of stepwise regression the variance in rumen $\mathrm{Mg}$ concentrations did not significantly contribute to the explained variance in $\mathrm{Mg}$ absorption. Thus, it seems that the observed changes in either rumen $\mathrm{pH}$ or rumen volume did not significantly affect rumen $\mathrm{Mg}$ concentrations and $\mathrm{Mg}$ absorption in our wethers fed different concentrations of $\mathrm{KHCO}_{3}$.

In conclusion, the present investigation indicates that raising the dietary $\mathrm{K}$ concentration from the low to high level ( 15.7 to $59.4 \mathrm{~g} \mathrm{~K} / \mathrm{kg} \mathrm{DM})$ produced an increase in PDt and a marked decrease in apparent $\mathrm{Mg}$ absorption. However, apparent $\mathrm{Mg}$ absorption was not further depressed when dietary $\mathrm{K}$ concentration was increased above $59.4 \mathrm{~g} \mathrm{~K} / \mathrm{kg} \mathrm{DM}$. This observation is important in relation to practical feeding of dairy cows where the amount of supplemental $\mathrm{Mg}$ is considered to be dependent on $\mathrm{K}$ intake. However, caution is warranted when quantitatively extrapolating the current findings to dairy cattle feeding. Contrary to what would be expected, urinary excretion of $\mathrm{Mg}$ in cows did not become marginally depressed when the dietary $\mathrm{K}$ content was increased from 48.0 to $75.5 \mathrm{~g} / \mathrm{kg} \mathrm{DM}$ (Jittakhot et al. 2003). However, in that study with cows, rumen $\mathrm{K}$ concentrations were $104 \mathrm{~mm}$ after the feeding of the ration containing $75.5 \mathrm{~g} \mathrm{~K} / \mathrm{kg} \mathrm{DM}$, whereas in the current study with sheep fed a ration with identical $\mathrm{K}$ level, the rumen $\mathrm{K}$ concentration was as a great as $150 \mathrm{~mm}$.

\section{Acknowledgements}

We thank Jan van der Kuilen for laboratory assistance and Anton Uijttewaal for biotechnical help. This study was supported by the Product Board Animal Feed (Productschap Diervoeder), The Hague, The Netherlands.

\section{References}

Association of Official Analytical Chemists (1984) Official Methods of Analysis, 14th ed. Arlington, VA: AOAC.

Axford RFE, Hughes A \& Evans RA (1982) Magnesium ammonium phosphate precipitation and its significance in sheep. Proc Nutr Soc 41, 85A.

Centraal Veevoederbureau (2003) Animal Feed Tables Book. Lelystad: CVB.
Dalley DE, Isherwood P, Sykes AR \& Robson AB (1997) Effect of in vitro manipulation of $\mathrm{pH}$ on magnesium solubility in ruminal and caecal digesta in sheep. J Agric Sci 129, 107-111.

Ferreira BM, Harrison FA, Keynes RD \& Nauss AH (1966) Observations on the potential across the rumen of sheep. J Physiol 187, 615-630.

Fisher LJ, Dinn N, Trait RM \& Shelford JA (1994) Effect of level of dietary potassium on the absorption and excretion of calcium and magnesium by lactating cows. Can J Anim Sci 74, 503-509.

Fontenot JP, Allen VG, Bunce GE \& Goff JP (1989) Factors influencing magnesium absorption and metabolism in ruminants. J Anim Sci 67, 3445-3455.

Greene LW, Fontenot JP \& Webb KE Jr (1983a) Effect of dietary potassium on absorption of magnesium and other macroelements in sheep fed different levels of magnesium. J Anim Sci 56, $1208-1213$.

Greene LW, Webb KE Jr \& Fontenot JP (1983b) Effect of potassium level on site of absorption of magnesium and other macroelements in sheep. J Anim Sci 56, 1214-1221.

Grings EE \& Males JR (1987) Effects of potassium on macromineral absorption in sheep fed wheat straw-based diets. J Anim Sci 64, 872-879.

International Dairy Federation (1986) IDF Standard 20A. Brussels: International Dairy Federation.

Jittakhot S, Schonewille JT, Wouterse H, Yuangklang C \& Beynen AC (2003) Apparent magnesium absorption in dry cows fed at three levels of potassium and two levels of magnesium intake. J Dairy Sci (In the Press).

Kemp A (1960) Hypomagnesaemia in milking cows; the response of serum magnesium to alteration in herbage composition resulting from potash and nitrogen dressing on pasture. Neth J Agric Sci 8, 281-303.

Khorasani GR \& Armstrong DG (1990) Effects of sodium and potassium level on the absorption of magnesium and other macro-minerals in sheep. Livest Prod Sci 24, 223-235.

Leonhard S, Martens H \& Gabel G (1989) New aspects of magnesium transport in ruminants. Acta Vet Scand 86, 146-151.

Leonhard-Marek S \& Martens H (1996) Effects of potassium on magnesium transport across rumen epithelium. Am J Physiol 271, G1034-G1038.

McLean AF, Buchan W \& Scott D (1985) The effect of potassium and magnesium infusion on plasma magnesium concentration and magnesium balance in ewes. Br J Nutr 54, 713-718.

Martens H \& Blume I (1986) Effect of intraruminal sodium and potassium concentrations and of the transmural potential difference on magnesium absorption from the temporarily isolated rumen of sheep. Quart J Exp Physiol 71, 409-415.

Martens H, Gabel G \& Strozyk H (1987) The effect of potassium and the transmural potential difference on magnesium transport across an isolated preparation of sheep rumen epithelium. $Q J$ Exp Physiol 72, 181-188.

Martens HS, Leonhard-Marek S, Lang I \& Schweigel M (1998) Sodium, potassium and magnesium in ruminants: interactions and antagonisms. Proceedings of the 10th International Conference of Production Diseases in Farm Animals, pp. 17-27 [T Wensing, editor]. Wageningen: Wageningen Pers.

Newton GL, Fontenot JP, Tucker RE \& Polan CE (1972) Effects of high dietary potassium intake on the metabolism of magnesium by sheep. J Anim Sci 35, 440-445.

Perkin-Elmer (1982) Analytical Method for Atomic Absorption Spectroscopy Handbook. Norwalk, CT: Perkin-Elmer.

Poe JH, Greene LW, Schelling GT, Byers FM \& Ellis WC (1985) Effects of dietary potassium and sodium on magnesium utilization in sheep. J Anim Sci 60, 578-582.

Quinlan KP \& DeSesa MA (1955) Spectrophotometric 
Determination of Phosphorus as Molybdovanadophosphoric Acid. Anal Chem 27, 1626-1629.

Rahnema SH \& Fontenot JP (1986) Effect of potassium on association of minerals with various fractions of digesta and feces of sheep fed hay. J Anim Sci 63, 1491-1501.

Ram L, Schonewille JT, Martens H, Van't Klooster AT \& Beynen AC (1998) Magnesium absorption by wethers fed potassium bicarbonate in combination with different dietary magnesium concentrations. J Dairy Sci 81, 2485-2492.

Rogers PAM \& Van't Klooster AT (1969) The fate of Na, K, Ca, $\mathrm{Mg}$ and $\mathrm{P}$ in the digesta. In Mededelingen Landbouwhogeschool, pp. 26-39. Wageningen.

Schonewille JT, Beynen AC, Van't Klooster AT, Wouterse H \& Ram L (1999a) Dietary potassium bicarbonate and potassium citrate have a greater inhibitory effect than does potassium chloride on magnesium absorption in wethers. J Nutr 129, 2043-2047.

Schonewille JT, Ram L, Van't Klooster AT, Wouterse H \& Beynen AC (1997) Intrinsic potassium in grass silage and magnesium absorption in dry cows. Livest Prod Sci 48, 99-110. Schonewille JT, Van't Klooster AT, Wouterse H \& Beynen AC (1999b) Effects of intrinsic potassium in artificially dried grass and supplemental potassium bicarbonate on apparent magnesium absorption in dry cows. J Dairy Sci 82, $1824-1830$.

Scott D (1966) The effects of sodium depletion and potassium supplements upon electrical potentials in the rumen of the sheep. $Q J$ Exp Physiol 51, 60-69.

Tomas FM \& Potter BJ (1976) The site of magnesium absorption from the ruminant stomach. Br J Nutr 36, 37-45.

Van't Klooster AT (1967) De toestand van calcium, magnesium en enkele andere mineralen in darminhoud en mest van herkauwers in verband met hun resorptie (The state of calcium, magnesium and some other minerals in gut contents and feces of ruminants in relation to their absorption). $\mathrm{PhD}$ Thesis, Utrecht University, The Netherlands.

Wilkinson L (1990) SYSTAT: The System for Statistics. Everton, IL: SYSTAT Incorporation.

Wylie MJ, Fontenot JP \& Greene LW (1985) Absorption of magnesium and other macrominerals in sheep infused with potassium in different parts of the digestive tract. J Anim Sci 61, 1219-1229. 